\title{
Overvejelser om positioneret deltager-observation Sexede astronomer og kønnede læreprocesser
}

Af Cathrine Hasse

Artiklen satter fokus på den epistemologiske forskel på at vare mandlig og kvindelig forsker ud fra en diskussion af den antropologiske metode sine qua non, feltarbejdet, der her er defineret som positioneret deltager-observation.

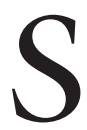

iden feminister som Donna Haraway, Sandra Harding og Evelyn Fox Keller begyndte at skrive om situering, "feministisk epistemologi" og videnskabens maskuline dominans, er det blevet stadig mere vanskeligt at opfatte forskeren som en neutral distanceret analytiker. De tre feminister har om nogen gjort det klart, at forskeren ser fra "somewhere" snarere end "nowhere". Krop, viden og mobilitet er uadskillige. Ureflekteret objektivitet hviler på "gudetricket", hvor forskeren foregøjler at se og forstå alt. Alene gennem en erkendelse af, at der altid ses fra "somewhere in particular" kan forskeren, ifølge Donna Haraway, gøre sig håb om at opnå den eneste mulige form for objektiv viden - den form for objektivitet hun kalder "situated knowledge" (1991, 188).1

Det gælder for forskeren om at opnå bevidsthed om sit eget "somewhere". Sandra Harding har påpeget, at denne erkendelse ikke medfører, at vi kan tale om en særlig feministisk metode eller metodologi, men 
om en særlig erkendelsesmåde, der inddrager og medtænker forskerens begrænsede perspektiv (Harding 1987). Hun har, som Fox Keller og Haraway lagt vægt på, at feministisk forskning adskiller sig fra den traditionelle maskulint dominerede metodeforståelse ved at medtænke relationen mellem viden og situering.

Antagelse i det foreliggende argument er, at vi som forskere må medtænke at mænd og kvinders forskningsepistemologi er knyttet til deres position. Det er en erkendelse, der er svær at komme uden om, når forskerens videnskabelige resultater søges gennem interaktion med andre mennesker (modsat forskere der udelukkende arbejder med skriftlige kilder, naturligt eller menneskabte materialer o.l.). For etnografer på feltarbejde, der søger midlertidigt ophold i fremmede kulturer for at forstå, hvad der bevæger de mennesker, der befolker dem bliver metodologiske refleksioner over forskerpositionen særligt påtrængende.

Deltager-observation er som metode lige velegnet for såvel feminister, som ikke-feminister, mænd og kvinder. Spørgsmålet der rejser sig er, om anvendelsen af den i en vis forstand samme metode fører til forskellige kønsbestemte videnskabelige erkendelser fordi mandlige og kvindelige forskeres positioner - på visse måder - er forskelligt betinget af de læreprocesser, der forandrer feltarbejderen i mødet med en bestemt verden.

\section{FELTARBEJDET DEKONSTRUERES}

"Deltager-observation" anvendes normalt som en ret uproblematisk betegnelse for etnografens (her benyttet som betegnelse for antropologen på feltarbejde) tilstedeværelse i en fremmed kultur. Når denne tilstedeværelse skal specificeres nærmere kan det ske med henvisning til, hvem og hvad der observeres eller med en uddybet redegørelse for etnografens anvendelse af de langt mere metodologisk funderede metoder som interview, fokusgruppeinterview, survey, brug af foto, video, feltnoter m.v.
Selve den proces, det er at være til stede i felten, har været genstand for ganske få refleksioner. I de senere år er denne antropologiske metode sine qua non, deltager observationen, primært blevet problematiseret i takt med, at begreber som "felt" og "kultur" er blevet dekonstrueret, redefineret eller opløst (se eksempelvis Olwig \&Hastrup, 1997, Appadurai 1995, Gupta \& Fergusson 1997, Clifford \& Marcus 1986). Dekonstruktionen har gjort det nødvendigt at trænge dybere ned i en forståelse af den etnografiske deltager-observation. Hvis felt og kultur er konstrukter, der opstår i ud fra feltarbejderens mere eller mindre fordomsfyldte observationer og øvrige sansninger, hvad er så egentlig dette "mystiske feltarbejde", som James Clifford (1988) benævnte det $\mathrm{i}$ en kritik af fagets manglende stillingtagen til sine egne myter?

Clifford opfatter begrebsparret "deltager-observation" som ubrugeligt. Der er blot tale om et forsøg på at videnskabeliggøre, hvad der er ren intuitiv indlevelse og personlig viden. Han forslår i stedet en reformulering i hermeneutiske termer, der peger på forskerepistemologien som en dialektik mellem erfaring og fortolkning (Clifford 1988,34). Det er et skift, der understreger det fortolkende fremfor deltagelsen. Efter således at have dekonstrueret den antropologiske autoritet, søger Clifford desuden at genoprette den ved at foreslå, at etnografen lader de indfødte selv komme til orde.

Jeg har foreslået begrebs-parret deltagerobservation opretholdt, men udvidet med en erkendelse af, at observation er betinget af, hvorledes etnografen deltager, og deltagelse er forbundet med positionerede kulturelle læreprocesser (Hasse 2000). Det er metodologiske refleksioner over læreprocessen, der gør det muligt at problematisere et af de begreber Clifford tager for givet - "de indfødte".

"De indfødte" udtrykker for en forestilling om et "os som forskersubjekter" over for et "dem som forskningsobjekter". Når 
antropologien i stigende grad gør det tilsyneladende hjemlige til sit analytiske objekt, rejser der sig nye metodologiske spørgsmål for faget. Når begreber som "felt" og "kultur" făr nye betydninger som relationssystemer (Hastrup 1989) gælder det samme så ikke forestillingen om "de indfødte"? Dette spørgsmål rejste sig for mig i forbindelse med mit feltarbejde blandt fysikstuderende på Niels Bohr Institutet for fysikstudier $\mathrm{i}$ København.

\section{LÆREPROCESSEN}

I det følgende vil jeg give to eksempler på, hvorledes min kønsposition gav anledning til videnskabelig refleksion i mødet med fysikernes verden på Niels Bohr Instituttet i København. Jeg vil dog også argumentere for, at skønt forskeren formentlig altid vil blive kønspositioneret er der også visse metodologiske valg knyttet til det, at indtage en social position.

Jeg indskrev mig, med instituttet og mit rusholds tilladelse, som fysikstuderende med det formål at bidrage til indsigt i, om kulturelle forståelser kan fungere som kønsbarrierer. Jeg lærte til en vis grad en fremmed kultur at kende - et nyt erfaringsrum, en verden (Hastrup 1989, 16). Den mangedobbelte identitet som antropolog, fysikstuderende og kvinde og det at lave feltarbejde i Danmark bidrog til en skærpet opmærksomhed på metodologien bag det antropologer betegner som "deltager-observationen" og "feltarbejde".

Feltarbejdere foretrækker generelt at fastholde deres identitet som forskere, fremfor bevidst at søge måder, hvorpå de kan overskride forskerrollen ved at deltage i de samme aktiviteter som de øvrige deltagere "de indfødte".

Det kan være ganske ubehageligt for antropologen, at deltage i de samme aktiviteter som feltens øvrige deltagere ikke mindst fordi det overskrider forestillingen om et fast etableret subjekt-objekt forhold. Mennesker er uafladeligt engagerede i en form for essentiel refleksivitet, hvor vi tolker og tilskriver hinanden identiteter og intentioner på baggrund af vores erfaringer. Ved at erkende sin deltager-position bliver forskeren et objekt for sin egen undersøgelse og kan erkende sig selv som objekt for andres evalueringer. Erkendelsen medfører, at forskersubjektet mister den autoritet, der ligger $\mathrm{i}$ at tro sig feltets eneste bedømmer. Ved at deltage $\mathrm{i}$ hidtil ukendte aktiviteter udsætter forskeren sig yderligere for andres evalueringer. Som den professionelt nyankomne er etnografen ofte uvidende om ting børn har lært for længst. For at kunne deltage i de samme aktiviteter som feltens mere rutinerede deltagere tvinges etnografen ind i novice-rollen og udsætter sig dermed for latterliggørelse. ${ }^{2}$ Der er dog ikke altid tale om, at etnografen er den eneste (voksne) nyankomne. I det levende prakisrum er der mange kulturmøder, hvor erfarne udpeger nye forskelle for den nyankomne i det fysiske rum.

På uddannelsesinstitutionerne er det ofte de mere erfarne ældre studerende, der viser de nyankomne rundt, og selv blandt "indfødte" danskere vil etnografen lære en ny verden at kende. Når kroppen bevæger sig gennem det fysiske rum, socialt medieret af de erfarne guider, forandres den verden, vi troede at kende. Processen ændrer relationen mellem sprog og verden - epistemologiens centrale omdrejningspunkt (Hastrup 1995; 1987, Ardener 1989). Det ændrer det kulturelle bevidsthedsrum og bestemmer gradvis det fysiske rum på nye måder. Samtidig tillægges omgivelser og vores egen fremtoning en ny moralsk værdi. Vi lærer ikke alene af at se, høre og sanse, men af at blive set, hørt og sanset, og af at reflektere begge former for sansninger (Hasse 2000, 10).

Moralsk evaluering kan give en deltager, hvad man med et italiensk udtryk i hofetikkette i 1600-tallet, kan betegne som sprezzatura (Biagioli 1995). Sprezzatura kan gxlde som betegnelse for den enkeltes handleviden, dvs. inkorporerede viden om, 
hvordan man opfører sig, der i mødet med en bestemt verden bliver de korrekte fysiske bevægelser, fremtrædelsesformer og tilstedeværelser (Hasse 2000, 20). Hvis man ikke opfører sig korrekt, evalueres man ofte ordløst ved små tegn på misbilligelse såsom himmelvendte øjne, løftede øjenbryn osv.

Disse tavse tegn făr os til at reagere, eller med den amerikanske filosof John Dewey ord, fremkalder omgivelsernes handlinger visse svar (Dewey 1916, 23). Ved hjælp af, ofte usproglige og ganske subtile midler, disciplinerer omgivelserne på måder, der for den enkelte får karakter af selvcensur. Derigennem lærer vi gradvis, hvem vi er i en bestemt verden, og om vi bør tilpasse os for at have sprezzatura. Det interessante ved alle sociale positioner, inklusive positionen som studerende, er ikke alene det, vi $e r$, men det vi bliver igennem sociale situationer (Hasse 2000, 10-11). At lære en verden at kende er følgelig ikke alene et spørgsmål om fysisk tilstedeværelse, men om positioneret social tilstedeværelse. Ved at deltage i aktiviteterne som fysikstuderende lærte jeg meget nyt, der hverken var udtryk for en umiddelbar intuitiv indlevelse eller fortolkninger alene baseret på min personlige viden som forsker. Jeg lærte, at fortolke en verden ved at deltage positioneret som fysikstuderende.

\section{DELTAGER-POSITIONEN}

Positionen betinger de relationer, der umiddelbart udpeger det fysiske rum. I dette tilfælde var jeg positioneret som både forsker og fysikstuderende og det fik konsekvenser for mine handlinger og erkendelser.

I feltarbejdets første fase var jeg opmærksom på mine medstuderendes ydre fremtrædelsesformer og sociale optræden. Deres køn, hvem der gik sammen med hvem, men også deres tøj og hårlængder. Jeg blev gang på gang overrasket over at møde studerende, der var anderledes end jeg havde forestillet mig. Min stereotype opfattelse af en mandlig nørd med ternet skjorte, tykke briller og musefarvet hår blev udfordret $\mathrm{i}$ mødet med unge kvindelige fysikstuderende, der gik i lyserøde, lårkorte kjoler, mænd i spraglede skjorter, californiske solbriller og røde læderjakker. Jeg havde nogle særlige forestillinger knyttet til, hvad man kunne kalde den sociale rolle som fysikstuderende.

Som påpeget af Martin Hollis lærer og erfarer vi gennem de sociale roller, vi indtager og dermed bliver de sociale roller inkorporeret som selv. Vi lærer blandt andet, hvordan de sociale roller skaber og begrænser muligheder, (Hollis 1985, 231). De sociale roller, forstået som de sociale forventninger til udfyldelsen af den sociale kategori, kan ikke spilles, men må erfares som en integreret del af ens identitet (Hasse 1995). Ved at indtage positionen som fysikstuderende lærte jeg, som Kirsten Hastrup har udtrykt det, "at se med andres øjne" (Hastrup 1992, 45).

Etnografer er generelt karakteriseret ved $i k k e$ at have noget ønske om at blive varigt medlem af den gruppe (eller de grupper), de studerer. Derfor vil antropologen aldrig kunne blive helt som de øvrige deltagere i felten. Hun har et andet formål med sin tilstedeværelse: at søge at forstå verden gennem analyse. Vi er dog aldrig helt distancerede, fordi vi i stigende grad lærer at tolke bestemte verdener. Det er læreprocessen, der medfører, at vi aldrig bare fortolker ud fra vores erfaring (som hævdet af Clifford), men at vores erfaringer og fortolkninger er knyttet til, hvorledes vi deltager.

Vi lærer gradvis at tilskrive nye betydning til begivenheder $\mathrm{i}$ en fremmed verden ud fra den position, vi indtager. I starten af feltarbejdet modtager vi mange signaler, der gør os forvirrede og overrasker, for derefter at blive internaliseret som det txppe af redundans, nye erkendelser kan træde frem på. Vi bliver gradvist i stand til at tolke de situationer, vi indgår i, ud fra et refleksionsgrundlag, der nærmer sig de øvrige deltageres.

Denne proces kan forstås som positioneret deltagelse. Uanset hvor neutralt og di- 
stanceret vi opfatter vores tilstedeværelse indgår feltarbejdere altid som deltager i et socialt rum, hvor vi fortolkes af og tolker, de øvrige tilstedeværende. Vi indtager med andre ord positioner, der gør en forskel i forhold til hvorledes vi opfatter det "samme" fysiske rum. Disse positioner giver os et bestemt blik på verden, vi ser fra et "somewhere", og det er min pointe, at vi kan indtage forskellige positioner, men at vi altid deltager positioneret.

Positioner er noget der gives mulighed for eller som vi påtvinges. Feltets øvrige deltagere tildeler antropologen positioner, der opstår ud fra den bestemte verdens aktiviteter, hvad enten antropologen er bevidst om positionerne eller ej. Samtidig har antropologen også en egen definition af sig selv i felten, der ligeledes spiller en rolle for, hvilken social udpegning, der finder sted. Selv når antropologen vælger at definere sig som en observatør, der deltager fra sidelinjen, vil hun altid være en deltager, der observerer fra bestemte positioner bestemt af denne specifikke verdens interesser. Selv når jeg definerede mig som "forsker", blev jeg i denne bestemte verden tolket ud fra denne verdens bestemte interesser (Hasse 2000, 168-169).

\section{KøNNET DELTAGER-POSITION}

Fysikstuderende og forsker kan siges at være sociale kategorier på linje med "dommer" eller "lærer", hvortil der er knyttet visse forventninger til en udfyldning af kategoriens sociale rolle. Men også køn kan forstås som en position, hvortil der knytter sig visse sociale forventninger, der kan skifte fra kultur til kultur. Sprezzatura handler om vi, ud fra en bestemt verdens præmisser, udfylder kategorien korrekt, hvad enten der er tale om positionen som dommer, fysikstuderende eller kvinde.

Kroppe er kønnede kroppe. De evalueres efter om vi lever op til de sociale forskrifter, der knyttes til at være mand eller kvinde $\mathrm{i}$ en bestemt verden. Som Dorte Marie Søn- dergaard bemærker, kan enhver kulturel aktør i reglen udpege mænd og kvinder i en forsamling (Søndergaard 1996, 90). Omverdenen spejler enkeltaktøren på grundlag af kropstegn. ${ }^{3}$ Denne spejlen og dens forbindelse til kroppen gør køn til et af de væsentligste bindemidler i selvet (ibid:91).

Adfærd eller fremtoning klassificeres følgelig ikke alene af forskeren, men af aktørerne selv, hvis klassifikationer igen klassificeres (Bourdieu 1984). Det er ikke det, at vi går og står forskelligt, men det at det tillægges forskellig værdi af de forskellige aktører. Det giver grobund for forskellige evalueringer, hvilket medfører, hvad Bourdieu kalder regulering. Individers handlemuligheder kan beskrives som regulerede improvisationer. Handlemuligheder kan ikke adskilles fra den praksis, der producerer dem (Bourdieu 1977, 37). Social spejlen på grundlag af tegnet er en moralsk spejlen, der gør os opmærksomme på, hvad der gælder som sprezzatura i en bestemt verdens praksis, og sprezzatura er knyttet til aktørers kønnede fremtrædelsesformer. Vi lærer også den bestemte verden at kende qua reaktioner på vores køn.

Da mennesker endvidere bærer erfaringer med andres evalueringer af deres kønnede kroppe med sig i kroppene, tolker vi igen andre ud fra disse kønnede, tidligere internaliserede erfaringer. Dette giver i visse situationer kvinder og mænd forskellige grundlag at reflektere ud fra også selv om de indtager sociale positioner, der ikke umiddelbart skulle give anledning til kønsmæssige refleksioner.

Ved at deltage som fysikstuderende kom det til at betyde noget for min indtagelse af positionen, hvorledes de andre fysikstuderendes evaluerede min påklædning, hvilket umærkeligt og ordløst medførte en synlig tilpasning. Jeg lærte efterhånden, at det at indtage en social rolle, som fysikstuderende, kræver social accept af, at jeg udfylder rollen korrekt, hvilket medførte, at jeg (til en vis grad) tilpassede mig det, jeg lærte var sprezzatura i denne bestemte verden. 
Min første tids overraskelse over de fysikstuderende i korte kjoler ændredes til en ny overraskelse, da jeg bemærkede, at mine kvindelige medstuderende ændrede tøjstil i mindre iøjefaldende retning. For ikke at falde udenfor, begyndte jeg også selv at klæde mig mere diskret. Jeg ændrede gradvist klædedragt fra lejlighedsvis at gå i korte nederdele og farvestrålende tøj til primært at gå i lange bukser og diskrete farver. Samme tendens noterede jeg hos mine kvindelige medstuderende, bortset fra en enkelt, der forsat gik i endog meget korte skørter. Efter fire måneders studier kunne en kvindelig medstuderende udbryde, at: "Nu har Vianna da endelig fået noget fornuftigt tøj på”, fordi hun kom til en fest i lange bukser (Hasse 2000, 199).

Det er ikke muligt for alle forskere at deltage ved at indtage hvilke som helst sociale kategorier. Vi har kun mulighed for at udfylde de sociale roller, der som defineret af Martin Hollis, er i overensstemmelse med vores selv (1985). ${ }^{4}$ At jeg overhovedet kunne forsøge at indtage en position som nyankommen deltager sammen med andre nyankomne deltagere i felten skyldtes mit feltarbejdes særlige karakter, hvor jeg, som professionelt nyankommen antropolog, fulgte en anden gruppe nyankomne de forsteårsstuderende gennem første studieår. Jeg kunne "følges med" de andre nyankomne ved at indtage en social position som fysikstuderende, fordi jeg selv (til dels) kunne leve op til de krav og forventninger, der var til udfyldelsen af netop denne sociale kategori. ${ }^{5}$

Disse overvejelser giver mulighed for at stille nye spørgsmål til om en metodologisk forståelse af deltager-observationen bør medtænke kønspositioneret epistemologi, hvor det om du er mandlig eller kvindelige forsker har betydning for, hvilke positioner du kan indtage og erkende fra i felten.

\section{OVERSKRIDELSE AF KØNSPOSITIONER}

For at tage det mest simple argument for, at det må forholde sig således. Først: der er

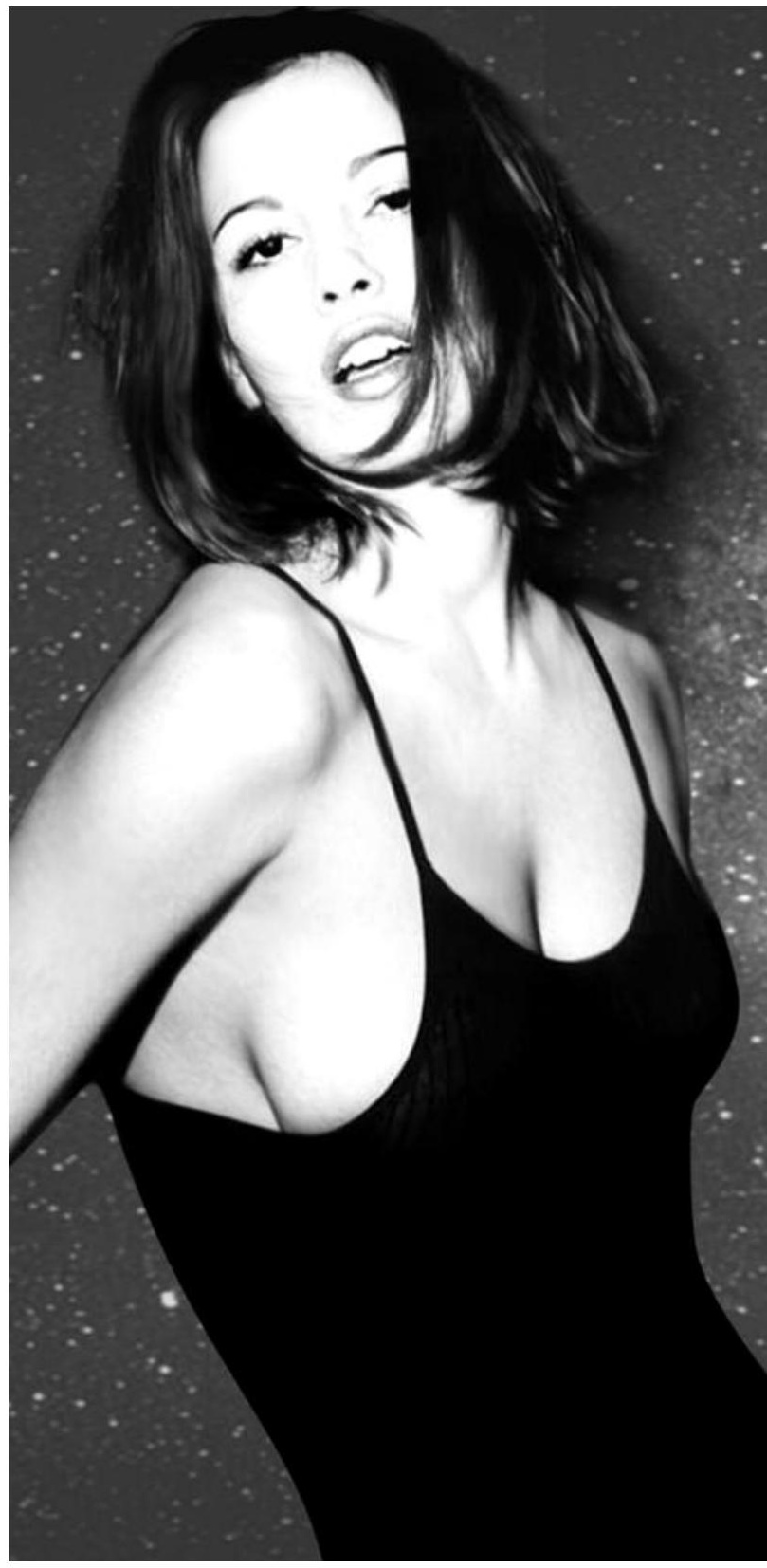

En sexet astronom - et forskerobjekt

i nogle kulturer i højere grad end andre forskellige forventninger til hvilke sociale kategorier, der kan udfyldes af mænd og kvinder. Dermed er der også forskel på, fra hvilken position etnografen erkender den verden, der bliver genstand for analysen. I sit feltarbejde på Island deltog Kirsten Ha- 


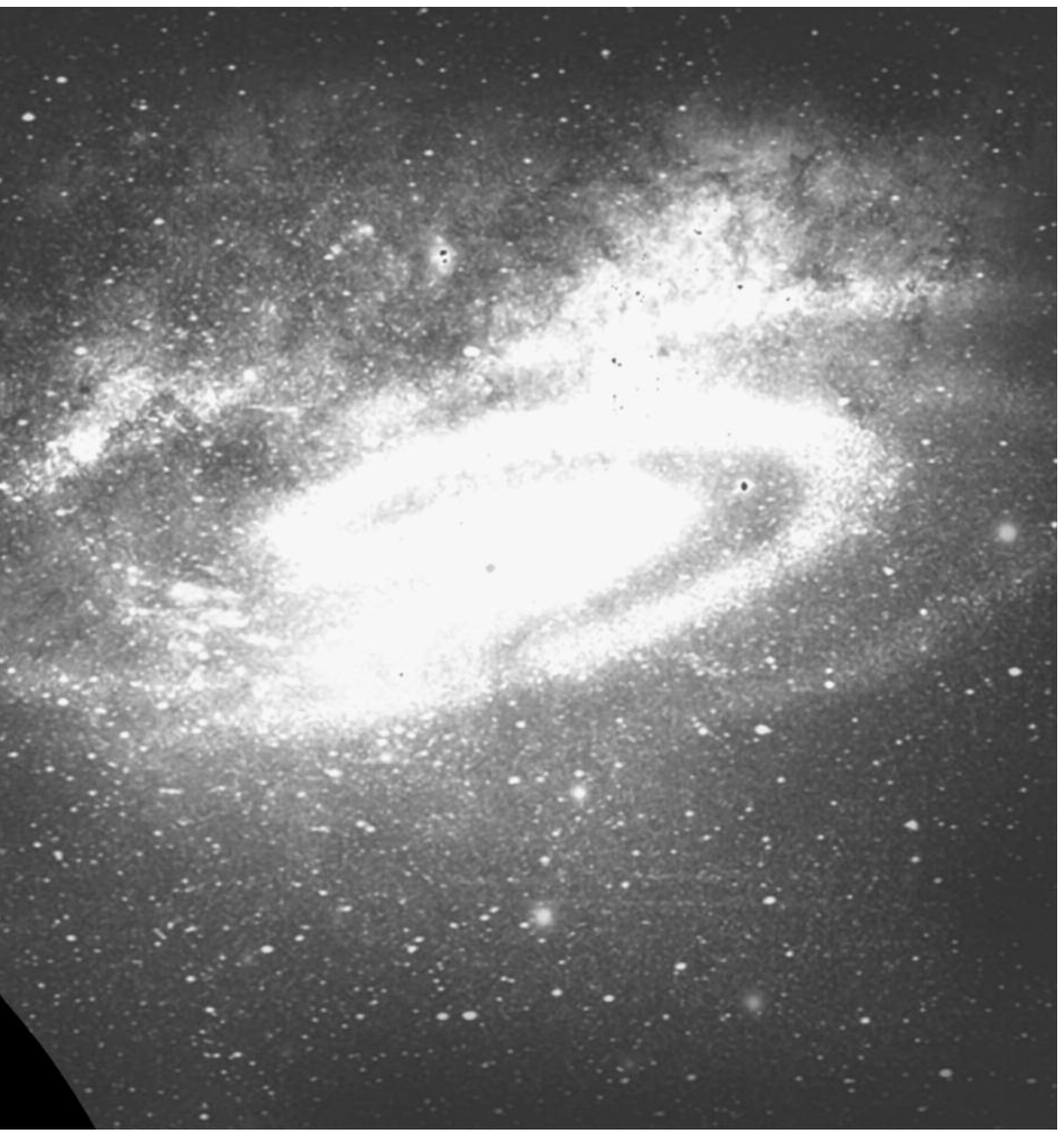

strup som malkepige på en gård (Hastrup 1989), hvor en mandlig antropolog højst sandsynligt ville have indtaget positionen som karl. Dermed ville han have erkendt verden gennem deltagelse i de kønsbestemte aktiviteter, der er knyttet til karlens snarere end malkepigens position.
Når feltarbejderen bevæger sig over de grænser for kønsadfærd, der udstikkes af de sociale roller, synes selve kønnet at få en fremtrædende plads i analyserne. Deltagernes forventninger til, hvorledes aktøren skal udfylde en social rolle, kan omfatte forventninger til relationen mellem køn og social 
kategori, hvilket igen kan præge, hvilke erkendelser der fremtræder som væsentlige. Ved en senere lejlighed deltog Hastrup eksempelvis i flere aktiviteter, der normalt er knyttet til mændenes verden på Island, som indsamler af får på fjeldet og som deltager $\mathrm{i}$ en vædderudstilling (Hastrup 1990; 1989). I den bestemte islandske verden var der i begge tilfælde tale om en kvinde, som placerede sig som "matter out of place". I begge tilfælde affødte deltagelsen fra denne epistemologiske position erkendelser om kønnets betydning. I modsætning til analyserne der udspringer af deltagelsen som malkepige, er Hastrups analyser af etnografens rejse ind i mændenes verden på Island prægede af en erkendelse af en mandeverden set fra positionen som kvinde, hvor det der fylder analyserne er refleksioner over mændenes reaktioner på den "forkert" positionerede kvinde (eller kvinden-som-barn).

Overskrider etnografen de grænser, den pågxldende kultur har sat for den kønnede indtagelse af sociale kategorier, vil erfaringerne med at indtage en "forbudt" position naturligt kunne give de videnskabelige refleksioneren et fremtrxdende fokus på køn. Det at være kønnet som henholdsvis mand eller kvinde synes i dette tilfælde at kunne blive et vigtigt grundlag for erkendelse og analytisk refleksion.

I nogle tilfælde indtager etnografen dog en "forsker"-position, som er så fremmed for den pågældende kultur, at kønnet ikke placerer vedkommende i nogen lokalt kendt mand/kvinde position. Det er, hævder den britiske antropolog Edwin Ardener, ofte tilfældet med de kvindelige antropologer, der, i lighed med deres mandlige kolleger, i mødet med de fremmede kulturer blev udelukket fra en indsigt i de lokale kvinders verden (Ardener 1989, 76).

\section{KØNSPOSITIONERET ERKENDELSE}

Når vi indtager positioner, hvortil der ikke stilles specifikke lokale kønskrav til udfyldelsen af de sociale kategorier, bliver argu- mentet lidt mere komplekst. Det var tilfældet, da jeg indgik som "fysikstuderende" en tilsyneladende kønsneutral kategori. Det at jeg er kvinde, hverken hindrede eller provokerede til en skærpet opmærksomhed på kønnet ved min indtagelse af kategorien. Skønt fysikstudiet på mange måder fremstår som en mandeverden er en femtedel af de studerende kvinder. Vores tilstedeværelse fremkalder hverken reaktioner hos de mandlige eller kvindelige deltagere i det daglige, der minder om Hastrups tilstedeværelse under vædderudstillingen på Island. I mange, mange situationer havde jeg andre vanskeligheder ved at udfylde kategorien end mit køn (eksempelvis var mit kendskab til fysik ganske mangelfuld, da jeg er nysproglig student) - men i nogle situationer synes kønnet alligevel på subtile måder "at trænge sig på”. Jeg indgik eksempelvis som fysikstuderende i nogle bestemte situationer, hvor jeg lærte, at det, der i denne bestemte verden forbindes med kvindelighed og det, der forbindes med fysik, er svære at forene.

På rusturen blev jeg, sammen med 40 andre kommende studerende på Niels Bohr Instituttet, introduceret for faget fysik ved at lærerne introducerede deres kommende kurser. En af lærerne havde til sin introduktion til sit kursus i efterårssemestret medbragt en smart computer, der kunne projicere levende billeder op på et lærred. Det følgende er en båndudskrift af præsentationen, der giver et eksempel på, at kønnet kan "trænge sig på" i analysen.

Læreren har netop vist os en undervisningsbog i astronomi på storskærmen og skifter nu til et andet program, der humoristisk skal vise, at lærerne snart kan erstattes af computere.

Larer (mand): Vi skal måske tage et andet klip. En guided tur af mælkevejen... [Anerkendende Uhh-råb (mænd), musik og latter - en kvinde letpåklædt i selskabstøj toner frem på stjernehimlen på lærredet - begejstrede studenter-kommentarer (mænd) i 
baggrund. Kvinden taler med en kælen stemme og tyk italiensk accent] ... Look up on a clear night and you will see a hazy weaser of light across the sky. The galactic home - the milky way - a pancake.

[Råb (mænd) om at hun skal komme igen, da kvinden forsvinder].

Studenterkommentar (mand): Jeg ville føle mig fornærmet, hvis der vadede sådan en rundt inde i min computer

Lever: Fidusen er: læreren kan jo bare smutte, når den er startet [høflig latter] ... vi kunne jo tage en sidste prøve - Andromaeda [fumler] fik jeg den ikke taget med her? Jo. Det vil I måske også gerne have lidt forklaring til ...

[Kvinden toner frem igen - HØJ latter]

Lerer: Ja, I kan godt se det bliver jo ikke nemt at konkurrere efterhånden jo ... [Han går videre med Andromeda i forskellige stråleoptagelser].

Lerer: Det her er der næppe nogen spørgsmål til - og jeg kunne nok ikke svare på dem ... Nu ser vi om jeg kan komme ud af det her...

Studerende (mand) [hvisker ironisk]: Hvor var det spændende ...

\section{Laver: Har I mere at spørge om??}

Studerende (mand): Kan man programmere hende damen væk på UNIX-maskinen? [Latter...]

Lever: Nu er det for det første til Windows den er lavet den her, så jeg tror slet ikke vi kan køre den på UNIX og øh...

Studerende (mand): Hun var sgu da sød nok...

Lever: Og faktisk så ... så lagde du nok mærke til: Jeg klikkede på hende, når jeg ville ha 'hende ... [MEGET HØJ LATTER] og det vil sige man kan helt lade være med at klikke, så er du fri for det, men så bliver det jo så stille ikke? [Mere latter].

Lerer (til kritisk mandlig studerende): Kunne du ikke lide damen eller hva'?

Studerende (mand): Hun er så stor [I studenterslang betyder "stor" noget i retning af "helt skøn", og det er her sagt ironisk. Læreren går videre med at fortælle om andre ting.]

Episoden er at dømme efter tilskuernes umiddelbare kommentarer tilsyneladende ganske uskyldig. Læreren har blot villet underholde og har bestemt ikke tænkt sit videoklip som et indslag i kønsrolledebatten. Men som alt andet vi lærer i løbet af ruskurset og den efterfølgende studietid indgår også denne situation i den fortløbende læreproces. Det må bemærkes, at skønt vi var ca. 36 mænd og 9 kvinder i rummet, høres ingen kvinder ytre sig. Bagefter bliver det klart, at oplevelsen har lejret sig forskelligt i de tilstedeværende.

Nogle kvinder udtrykker skam på kvindekønnets vegne, fordi det føltes pinagtigt at blive konfronteret med den form for, hvad der opleves som stupid kvindelighed i denne faglige sammenhæng. Det gælder undertegnede og et par kvindelige studerende, jeg taler med bagefter. Det bliver ikke helt klart i samtalen, hvorfor vi føler os flove. Da jeg senere reflekterer over det, finder jeg frem til, at det var fordi skærmkvinden både var så ekstremt kvindelig og blev vurderet som så ekstremt dum i forhold til de bemærkninger, de andre kom med. Det pinagtige ligger blandt andet i den latter, der følger hver gang kvinden kommer til syne for at påråbe sig en faglig ekspertise som astronom. Latteren signalerer, at den respekt, der ville følge med en sådan ekspertise, får hun ikke, og det er nærliggende at forestille sig, at det er fordi hun spiller på sin kvindelighed ved at bære 
feminint tøj. Hun konnoterer sex snarere end faglighed at dømme efter kommentarer og reaktioner. Hun er en "sød" "dame" som man kan "klikke på når man vil have hende". Latteren signalerer, at det er selve kvinden snarere end de faglige kommentarer "man vil have". Nogle mandlige studerende bruger episoden til at klassificere læreren som "leflende" og kritiserer, at fysik og astronomi gøres til underholdning, atter andre mandlige studerende siger, at "hende ville de godt en tur i rummet med". Kvinden vurderes under alle omstændigheder som "ikke-faglig", men det er tydeligt, at mændene ikke selv føler sig ramt af denne evaluering. Kvinderne, derimod, reagerer som om også de er blevet evalueret på værende "lig med" kvinden på skærmen deraf skamfølelsen. Ikke over læreren, men over at de kan slås i hartkorn med dette tåbelige kvindemenneske, der ikke har forstand på fysik, men på selskabskjoler.

De forskelle jeg erfarer gennem min deltagelse positioneret som fysikstuderende kan ikke adskilles fra, at jeg har andre erfaringer end de øvrige deltagere. Jeg er qua mit forskningsprojekt optaget af kønnets betydning, men det er ikke alene derfor episoden virker stærkt på mig. Alle har egne erfaringer med at være kønnet, der ikke deles af alle andre. Alle deler i et vist omfang fælles erfaringer med at blive tolket ud fra vores køn. Nogen af os har det fælles, at vi er positionerede som kvinder. Der er ikke alene et spørgsmål om, at andre definerer os som sådan ved at udpege vores kvindelige kropstegn. I den ovenstånde episode taler vi ud fra nogle erfaringer, der forbinder os med det kvindelige på skærmen. Når både de to øvrige kvinder, og jeg selv giver udtryk for, at vi oplever episoden som flov og pinlig, kan det forklares ved, at vi, som kvinder på fysikstudiet, identificerer os med den kvindelige fysiker på skærmen, der latterliggøres.

Siden skal jeg, gennem lignende latterliggørelser af forbindelsen mellem kvinder i sexet tøj og fysik, lære, at sexet kvindelig- hed ikke kan forbindes med faglighed $\mathrm{i}$ denne kontekst. 6 Denne analytiske forståelse udspringer af min positionerede deltager-observation, der lærer mig en verden at kende fra et "somewhere" og dette "somewhere" omfatter både andres evalueringer af min kønsmærkede krop, deres evalueringer af andre med tilsvarende kønsmærkede kroppe og mine tidligere erfaringer og forestillinger om fremtidige evalueringer på baggrund af den kønsmærkede krop. Kroppens fremtoning og bevægelser gennem rummet bliver tilpasset og transformeret i forhold til, hvad jeg lærer er sprezzatura i den pågældende verden. Hvor dette faktum må siges at være et fælles vilkår for alle fremmede nyankomne, mænd som kvinder, kan der i visse tilfælde være tale om forskellige erkendelsesbetingelser, fordi mænd og kvinder også i denne verden til en vis grad indtager forskellige positioner. Ville en mandlig antropolog have erkendt episoden på en anden måde? Selv om vi her er ude i et yderst spekulativt ærende, tror jeg det forholder sig således alene af den grund at den mandlige etnograf ikke ville have følt sin egen personlige position truet af episoden. Ville en mandlig fotomodel og dressmand, der blev sat til at forklare fysikkens mysterier også bliver latterliggjort, og ville det have givet en mandlig fysiker eller etnograf en tilsvarende folelse af, at også han var blevet degraderet af episoden? Måske for så vidt, at han kunne identificere sig med fotomodellen snarere end med nørden. Her ville identifikationen dog ikke alene være betinget af, at fysikeren eller etnografen havde samme køn som fotomodellen - der skulle mere til. Det er måske den vigtigste forskel på mænds og kvinders positionerede deltager-observation: i fortrinsvise kvindeverdener vil den mandlige etnograf formentlig i højere grad kunne identificere sig med de få mænd, der er til stede, mens det i fortrinsvise kvindeverdener er den kvindelige etnograf, der i højere grad identificere sig med de øvrige kvinder.

Hvis kønnet definerer identiteter og er 
med til at forme den antropologiske indsamling af empiriske data og fortolkninger af andre verdener (Callaway 1995, 29), bliver spørgsmålet, hvorledes? Hvorledes påvirker det vores omverdens-erkendelser, at vi er mænd eller kvinder. Her er det klart, at en omverdens reaktioner på vores eget køn kan være en faktor. Det gælder dog også, på en lidt mere subtil måde, egne reaktioner på andres evalueringer af personer, der har samme køn som forskeren selv. Her kan der være tale om en egentlig epistemologisk forskel på, hvorledes en mandlig respektiv kvindelig forsker kan opfatte en situation. Andres evaluering af en kvinde vil ikke nødvendigvis have den samme effekt på en mand, mens det for de tilstedeværende kvinder (herunder forskeren) făr en personlig betydning skønt det ikke er deres sprezzatura, der evalueres, hvilket episoden med den sexede astronom er et eksempel på. I dette tilfælde var det min evaluering af en bestemt situation, hvor mit køn kom til at indgå i refleksionerne over min egen situation og fremtidige muligheder for at forblive fysikstuderende på instituttet, selv om jeg havde samme køn som den foragtede "sexede astronom".

Var der ligeledes et kønsaspekt knyttet til min tilpasning af min fysiske fremtoning til den sociale position som fysikstuderende? Ville en mandlig antropolog også have xndret tøjstil? Det forekommer ikke usandsynligt. Ud af fem mænd på mit hold med lange hestehaler havde fire klippet dem af efter de første måneder på studiet. Det lange hår signalerer, da det strider mod normen, en særlig optagethed af udseendet. Det er ikke alle, men mange studerende, der tilpasser sig og fjerner kropstegn, der i denne lokale sammenhæng konnoterer forfængelighed og seksuelt køn. Kvinden må ikke understrege sin feminine krop eller virke forfængelig, men heller ikke manden må i for høj grad konnotere maskulin"smartness" og forfængelighed.7 Jeg ændrede, som min eventuelle mandlige kollega, ikke tøjstil for at blive en nørd, eller for at "spil- le teaterrollen" som fysikstuderende, men for at blive accepteret.

I dette tilfælde kan metoden deltager-observation ikke egentlig siges at give den mandlige og kvindelige forsker forskellige refleksionsgrundlag, selv om der er tale om forskellige reguleringer. Den ene må klippe hestehalen af (eller lægge den røde læderjakke bort), den anden må undvære miniskørtet, men begge kan reflektere over, at de tvinges til at xndre fremtoning. Begge kan gennem positioneret deltagelse nå til samme forståelse af relationen mellem det at blive opfattet som seriøs fysikstuderende og det at fremstå som kropsoptaget.

\section{METODOLOGISKE VALG}

Epistemologi er forbundet med metodologi, fordi position og erkendelse ikke kan adskilles.

Feltarbejderen har et valg. Det valg, etnografen står $\mathrm{i}$, er ikke mellem at deltage eller observere, eller vælge, hvorledes de øvrige deltagere skal opfatte forskerens position. Det metodiske valg står mellem at deltage primært som observatør, og interviewer eller søge at kombinere med en aktiv deltagelse i de samme aktiviteter som feltens øvrige deltagere, hvor det er muligt. Observationen og refleksionen følger under alle omstændigheder positionen.

Vælger etnografen at deltage i samme aktiviteter som feltens øvrige deltagere bliver det klart, at der er mange valg forskeren ikke kan tage. En kropsmærket mandlig etnograf kan ikke vælge at erfare verden fra positionen som kvinde, men han kan fortsat, ud fra en bevidsthed om den bestemte verdens socialt bestemte kønsroller, vælge at overskride de sociale forventninger og studere reaktioner på sin egen overskridelse. Dette vil under alle omstændigheder give den mandlige feltarbejder et andet refleksionsgrundlag end, hvis han kunne indtage en position, der var i overensstemmelse med denne bestemte verdens forventninger til hans køn. 
Mandlige og kvindelige forskeres epistemologiske læreprocesser kan derfor på mange måder synes at være forskellige alt efter hvilke sociale kategorier, der byder sig til eller kan overskrides i forhold til deres køn. I nogle tilfælde vil de nå til meget forskellige erkendelser som baggrund for analysen af det antropologiske objekt, i andre vil kønnede erfaringer spille en meget lille rolle, mens det er andre krav og reaktioner på opfyldelsen af disse krav, der skaber grundlag for analysen.

\section{NOTER}

1.Jeg opfatter "situeret viden" som en generel konstatering af, at vi alle er positionerede subjekter også "gudetrickets" mester.

2. Etnografen kan være mere eller mindre novice, men måske også i nogle sammenhænge endog ekspert på de områder, der optager feltens øvrige deltagere, hvilket igen vil ændre den positionerede læreproces.

3. Betegnelsen "kropstegn" er hentet fra Dorte Marie Søndergaards grundige analyse af kønnethed blandt unge under uddannelse "Tegnet på kroppen" (Søndergaard, 1996).

4. Rolle forstået som dramatis personae kan i bruges i analyser af sociale institutioner og praksisser, hvor rolle er det dynamiske aspekt af en social position. Selv og social rolle er viklet sammen, men kan analyseres som adskilte fænomener. Når social teori knyttes til filosofier om selvet bliver det klart, at hvor selvet kan forstås som aktøren bag social handlen er det en moderne ide, at vi konstruerer vores egen sociale identitet (Hollis 1985, 107). 5. Jeg kunne eksempelvis dårligt indtage positionen som fysiklærer og i andre feltarbejder, ikke mindst $i$ andre verdensdele, vil der være andre begrænsninger end kønnet på, hvad feltarbejderen har mulighed for at deltage i af lokale aktiviteter - eksempelvis manglende færdigheder som danser, maskemager, åndemaner.

6. Argumentet er uddybet i Hasse 2000.

7. Jeg er ikke den eneste i lokalmiljøet, der bemærker disse transformative tilpasninger, der blandt andet optræder som omdrejningspunkt for et humoristisk indslag $\mathrm{i}$ årets Fysikrevy 1997.

\section{LITTERATUR}

- Appadurai, Arjun (1995): 'The production of locality' i Richard Fardon (ed) Counterworks -Managing the Diversity of Knowledge, London, Routledge. - Ardener, Edwin (1989): The Voice of Prophecy, Oxford, Basil Blackwell.

- Biagioli, Mario (1995): "Tacit Knowledge, Courtliness and the Scientist's Body" i Susan L. Foster (ed) Choreographing History, Bloomington, Indiana University Press

- Bourdieu, Pierre (1977/1995): Outline of a theory of practice, Cambridge, Cambridge University Press.

- Bourdieu, Pierre (1984): Distinction: a social critique of the judgement of taste, London, Routledge \& Kegan Paul.

. Callaway, Helen (1995):' Ethnography and experience - Gender implications in fieldwork and texts', i Judith Okely and Helen Callaway (eds.) Anthropology and autobiography, London, Routledge.

- Clifford, James (1988): The Predicament of Culture, Harvard, Harvard University Press.

. Clifford, James and Marcus, George E. (1986): Writing Culture: The Poetics and Politics of Etnography, Berkeley, University of California Press. - Dewey, John (1916/1966): Democracy and Education. An introduction to the Philosophy of Education, New York, The Free Press.

- Gupta, Akhil and Ferguson, James (1997): Anthropological Locations - Boundaries and Grounds of a Field Science, Berkeley, University of California Press.

- Haraway, Donna (1991): Simians, Cyborgs and Women, Free Association Books, London.

- Harding, Sandra (ed)(1987): Feminism and Methodology, Bloomington, Indianana University Press.

- Hasse, Cathrine (1995): 'Fra Journalist til "Big Mama", i Tao Kongsbak, John A. Larsen og Cathrine Hasse (eds.), Tidsskrifted Antropologi. Nr. 31. 'Metode', Copenhagen., AKA-Print. pp.5364.

- Hasse, Cathrine (2000): Kraftfeltet-kulturelle lareprocesser $i$ det fysiske rum, ph.d. afhandling. København, Institut for Antropologi.

- Hastrup, Kirsten (1987): 'The Reality of Anthropology', Ethnos, nr. 3-4, Stockholm, Etnografiska Museet, pp 287-300.

- Hastrup, Kirsten (1989): "Kultur som analytisk begreb”, i Kirsten Hastrup og Kirsten Ramløv (eds.) Kulturanalyse. Fortolkningens forløb $i$ antropologien, København, Akademisk Forlag.

- Hastrup, Kirsten (1992): Det antropologiske projekt om forbloffelse, Gyldendal, København. 
- Hastrup, Kirsten (1995): A Passage to Anthropology - between experience and theory, London, Routledge.

- Hollis, Martin (1985): Of Masks and Men, I The Category of the Person, Cambridge, Cambridge University Press.

- Olwig, Karen Fog og Hastrup, Kirsten (1997) (eds.): Siting Culture. The shifting anthropological object, London, Routledge.

- Søndergaard, Dorte Marie (1996): Tegnet på kroppen - Køn: koder og konstruktioner blandt unge voksne $i$ Akademia, Århus, Museum Tusculanums Forlag.

\section{SUMMARY}

The author give empirical examples from her fieldwork among physicist students in Copenbagen and discuss participant observation within a new methodological framework stressing that observation and participation is always positioned. Participant-observation is a generel method useful for men and alike. Even so the question raised by the author is whether this method leads to different genderdetermined research epistemologies as male and female scientists in some ways occupy two different positions in a particular social world, which leads to differences in evaluations and reactions and thereby to different epistemological processes and analyses of the object under study.

Cathrine Hasse er

Research Associate Professor, ph.d. ved Danish Institute of Advanced Studies in the Humanities, København

Email: cathrine.hasse@humanities.ku.dk 